\title{
Factors Related to Substantial Pain in Terminally Ill Cancer Patients
}

\author{
Sang-Yeon Suh, M.D., Ph.D., Kyung Po Song, M.D.*, Sung-Eun Choi, Ph.D. ${ }^{\dagger}$, \\ Hong-Yup Ahn, Ph.D. ${ }^{\ddagger}$, Youn Seon Choi, M.D., Ph.D. ${ }^{\S}$ and Jae Yong Shim, M.D., Ph.D." \\ Department of Medicine, Dongguk University, Seoul, *Department of Family Medicine, \\ Dongguk University Ilsan Hospital, Goyang, ${ }^{\dagger}$ Department of Gastroenterology, Asan Medical Center, \\ University of Ulsan College of Medicine, ${ }^{\mp}$ Department of Statistics, Dongguk University, \\ ${ }^{\S}$ Department of Family Medicine, Korea University Guro Hospital, "Department of Family Medicine, \\ Gangnam Severance Hospital, Yonsei University Health System, Seoul, Korea
}

\begin{abstract}
Purpose: Pain is the most common and influential symptom in cancer patients. Few studies concerning pain intensity in the terminally ill cancer patients have been done. This study aimed to identify factors related with more than moderate pain. Methods: This study used secondary data of 162 terminal cancer inpatients at the palliative ward of six training hospitals in Korea. Physician-assessed pain assessment was by 10 point numeric rating scale. Substantial pain was defined more than moderate intensity by the Korean National Guideline for cancer pain. The Korean version of the MD Anderson Symptom Inventory was self-administered to assess symptoms. Survival prediction was estimated by the attending physicians at the time of admission. Results: Less than six weeks of predicted survival and more than numeric rating of six for worst drowsiness in the previous $24 \mathrm{~h}$ were significantly related to substantial pain $(\mathrm{P}=0.012$ and $\mathrm{P}=0.046$, respectively). The dose of opioid analgesics was positively related to substantial pain $(\mathrm{P}=0.004)$. Conclusion: Factors positively related to substantial pain were less than six weeks of predicted survival and considerable drowsiness. Careful monitoring and active preparation for pain are required in terminal cancer patients having those factors. (Korean J Hosp Palliat Care 2011;14:197-203)
\end{abstract}

Key Words: Cancer pain, Predicted survival, Drowsiness

\section{INTRODUCTION}

Survival rates and life expectancies of cancer patients have increased with advances in modern medicine. One consequence has been an increase in the numbers of terminally-ill cancer patients. The symptoms occur together in most cancer patients (1). Especially cancer pain has the top priority to be controlled among the various symptoms (2), because the pain is the most distressing debilitating one (3).

Despite the abundant research on cancer pain, cancer pain still is a major problem; its prevalence was calculated to be

Received on July 20, 2011. Revised on August 4, 2011.

Accepted on August 5, 2011.

Corresponding author: Youn Seon Choi

Tel: 02-2626-3275, Fax: 02-837-0613

E-mail: younseon@korea.ac.kr as high as $64 \%$ in a meta-analysis (2). The World Health Organization pain ladder is used globally; appropriate drugs and dosages following WHO ladder recommendation could be adequately relieved cancer pain about 70 90\% of patients (4). Nevertheless, cancer pain remains challenging issue for the physicians to manage and factors related to cancer pain need further investigation (5).

For other health issues, identification and preferential management of those at high-risk has been proven to be prudent, both in terms of patient care and allocation of limited medical resources. A similar strategy seems germane for those experiencing cancer related pain. The simplest and most reliable assessment tool of pain is patient self-assessment using a 10-point numerical rating scale (NRS) (6). Substantial pain is defined as more than moderate pain (7). Moderate pain is usually $4 \sim 6$ on the NRS, however, in South Korea, national guidelines for cancer pain define moderate pain 5 or 
6 on the NRS $(8,9)$.

Presently, we defined substantial pain (moderate to severe pain) as $\geq 5$ on the NRS. We hypothesized that terminally-ill cancer patients experiencing substantial pain group would be a priority group for pain management, and that their pain has some characteristics of poorly controlled pain. The objective of this study was to investigate the factors related to substantial pain with the aim of delivering more effective pain care.

\section{MATERIALS AND METHODS}

\section{Participants}

Study participants were 162 terminally-ill patients from palliative care wards in six training hospitals in a metropolitan area of South Korea. This cross-sectional study used secondary data for development of an objective prognostic score (10). The study participants complied with the Korean version of the MD Anderson Symptom Inventory (11). Inclusion criteria were incurable cancer in the terminal stage confirmed by more than two physicians and inpatients for hospice care, an age $>18$ years, patient consent for study participation, and clinical prediction of survival of $<3$ months.

\section{Study method}

Patients were assessed at the time of admission by the attending physician. Demographic data and disease related factors (primary cancer site, metastatic site, treatment of cancer, daily dosage of opioid analgesics) were identified. Pain at the time of questioning was evaluated by the physician using the $0 \sim 10$ point NRS. Symptoms were assessed by the Korean version of the MD Anderson Symptom Inventory. A self-administered survey questionnaire was completed by patients, except those whose age or infirmity required the assistance of a medical intern. The functional status of patients was evaluated using the Eastern Cooperative Oncology Group (ECOG) performance score. The ECOG score varies from 0 (normal activity) to 4 (bedridden). Clinical predictions of survival (weeks) were estimated by the attending physician at the time of admission. The survey period was from November 2006 until June 2007. Informed written consent for the use of personal information was provided by all participants. The study protocol was approved by the Institutional Review Board of the Dongguk University Ilsan Hospital.

\section{Statistical analysis}

Pain intensities were divided into two groups according to previous studies $(7,9)$ and our national guideline (8). NRS $<5$ was defined as mild pain and NRS $\geq 5$ was defined as moderate-to-severe (substantial) pain. The Korean version of the MD Anderson Symptom Inventory assessed symptoms by enquiry as to the worst symptoms during the previous $24 \mathrm{~h}$. The answers showed a skewed distribution, therefore, they were categorized into two groups based on the $50^{\text {th }}$ percentile. The clinical estimation of survivals also showed nonparametric distribution, and so were divided on the basis of the median value of 6 weeks. All opioid analgesics used were calculated and represented an oral morphine equivalent (OME, mg/day) dosage. The ECOG performance status was categorized as $1 \sim 3$ and 4 . Comparisons of demographic variable of gender and disease related factors (primary cancer site, metastatic site, treatment against cancer, opioid dosage, accompanied symptoms, ECOG) between mild and substantial pain groups were made using the Chi-square test. Binary logistic regression was performed with significantly proven variables on univariate analysis. The final model was obtained by use of a backward stepwise selection procedure. All statistical analyses were performed with the SPSS statistical package for Windows version 16.0.2. The significance level was 0.05 for all statistical tests.

\section{RESULTS}

\section{General and clinical characteristics of participants}

Table 1 shows characteristics of patients in the study population. The numbers of men and women were 72 (44.4\%) and $90(55.6 \%)$, respectively, indicating no gender bias for the data. The mild pain and substantial pain groups both contained 81 people. Lung cancer was most common, followed by hepatobiliary cancer and gynecologic cancer. Previous cancer treatment was most commonly chemotherapy, followed by surgery and radiotherapy. The worst symptoms during the previous $24 \mathrm{~h}$ that significantly correlated with pain were fatigue, sleep disturbance, distress, 
Table 1. Characteristics of the Study Participants.

\begin{tabular}{|c|c|}
\hline & Number (\%) \\
\hline Total number of patients & 162 \\
\hline \multicolumn{2}{|l|}{ Sex } \\
\hline Men & $72(44.4)$ \\
\hline Women & $90(55.6)$ \\
\hline \multicolumn{2}{|l|}{ Pain scale $\left(0 \sim 10, \mathrm{NRS}^{*}\right)$} \\
\hline Mild (0 to 4 ) & $81(50.0)$ \\
\hline Moderate $(5,6)$ & $39(24.1)$ \\
\hline Severe $(7$ to 10$)$ & $42(25.9)$ \\
\hline \multicolumn{2}{|l|}{ Organ-related cancer } \\
\hline Lung & $37(22.8)$ \\
\hline Stomach & $25(15.4)$ \\
\hline Colon & $22(13.6)$ \\
\hline Ovary/cervix & $31(19.1)$ \\
\hline Hepatobiliary & $34(21.0)$ \\
\hline Pancreas & $10(6.2)$ \\
\hline Head/neck & $9(5.6)$ \\
\hline Soft tissue & $2(1.2)$ \\
\hline Renal/bladder & $6(3.7)$ \\
\hline Others & $16(9.9)$ \\
\hline \multicolumn{2}{|l|}{ Previous treatment } \\
\hline Operation & $73(45.1)$ \\
\hline Chemotherapy & $98(60.5)$ \\
\hline Radiation therapy & $55(34.0)$ \\
\hline Others & $4(2.5)$ \\
\hline \multicolumn{2}{|l|}{$\mathrm{ECOG}^{\dagger}$ performance status } \\
\hline 1 & $20(12.3)$ \\
\hline 2 & $26(16.0)$ \\
\hline 3 & $58(35.8)$ \\
\hline 4 & $58(35.8)$ \\
\hline \multicolumn{2}{|l|}{ Fatigue (median 5) } \\
\hline 0 to 5 & $68(42.0)$ \\
\hline 6 to 10 & $94(58.0)$ \\
\hline \multicolumn{2}{|l|}{ Sleep disturbance (median 6) } \\
\hline 0 to 6 & $80(49.4)$ \\
\hline 7 to 10 & $82(50.6)$ \\
\hline \multicolumn{2}{|l|}{ Distress (median 5) } \\
\hline 0 to 5 & $78(48.1)$ \\
\hline 6 to 10 & $84(51.9)$ \\
\hline \multicolumn{2}{|l|}{ Drowsiness (median 5) } \\
\hline 0 to 5 & $73(45.1)$ \\
\hline 6 to 10 & $89(54.9)$ \\
\hline \multicolumn{2}{|l|}{ Sadness (median 5) } \\
\hline 0 to 5 & $88(54.3)$ \\
\hline 6 to 10 & $74(45.7)$ \\
\hline \multicolumn{2}{|l|}{ Nausea (median 4) } \\
\hline 0 to 4 & $86(53.1)$ \\
\hline 5 to 10 & $76(46.9)$ \\
\hline \multicolumn{2}{|l|}{ Dyspnea (median 4) } \\
\hline 0 to 4 & $87(53.7)$ \\
\hline 5 to 10 & $75(46.3)$ \\
\hline Opioid usage, median (range) $\left(\mathrm{OME}^{\ddagger}, \mathrm{mg} / \mathrm{d}\right)$ & $30.00(0 \sim 660)$ \\
\hline
\end{tabular}

*NRS: numeric rating scale (0 to 10), ${ }^{\dagger}$ ECOG: Eastern Cooperative Oncology Group, ${ }^{\ddagger}$ OME: oral morphine equivalent. drowsiness and sadness. Scoring of symptoms was based on the $0 \sim 10 \mathrm{NRS}$, where 0 was absence of symptoms and 10 was the worst symptom imaginable. Symptom scores were divided into two groups based on the median. The median scores of each symptoms measured by MDASI-K are presented in Table 1. Median values of symptoms were 4 6. The median value of daily received opioid dosage was 30.00 OME (mg/day).

\section{Factors related to pain intensity}

Patients whose reported pain score was $<5$ formed the mild pain group and those whose pain was $\geq 5$ NRS formed the substantial (moderate-to-severe) pain group. Demographic variables, primary cancer site, treatment against cancer, clinical prediction of survival on admission, performance status (ECOG score), symptom scores measured by MDASI-K and daily opioid dosage were compared in both groups of patients. Age and gender differences were not significant. Primary cancer site and previous cancer treatment did not significantly influence pain intensity (data not shown). Clinical predictions of survival did significantly differ; in terms of the number of patients whose survival were predicted to be less than the median (6 weeks), the numbers in the substantial pain group $(\mathrm{N}=52,52.6 \%)$ was significantly worse than the numbers in the mild pain group $(\mathrm{N}=29,38.7 \%)(\mathrm{P}=0.001)$. Patients with declined functional status in the substantial pain group $(\mathrm{N}=38,46.9 \%)$ was significantly higher than the 20 persons $(24.7 \%)$ in the mild pain group $(P=0.003)$. Sleep disturbances (defined as NRS $\geq$ 7 for the sleep disturbance item in MDASI-K) were more frequently observed in the substantial pain groups than the mild pain group $(\mathrm{P}=0.028)$. Patients with drowsiness (defined as NRS $\geq 6$ for drowsiness item in MDASI-K) were much more numerous in the substantial pain group $(\mathrm{N}=55$, $67.9 \%)$ than in the mild pain group $(\mathrm{N}=34,42.0 \%)$ $(\mathrm{P}=0.001)$. However, differences in worst fatigue, distress and sadness during the previous $24 \mathrm{~h}$ between the pain intensity groups were not significant (Table 2). The median of opioid dosage (OME) in the substantial pain and mild groups was $60 \mathrm{mg} /$ day (range $0 \sim 390$ ) and $19 \mathrm{mg} /$ day (range $0 \sim 660$ ), respectively, and was significantly (P $<0.001)$. Multivariate logistic regression was performed on pain and correlates. Significantly related factors to substantial 
Table 2. Univariate Analysis of Clinical Variables by Pain Group (N, \%).

\begin{tabular}{|c|c|c|c|}
\hline & $\begin{array}{c}\text { Pain NRS }<5 \\
\quad(N=81)\end{array}$ & $\begin{array}{c}\text { Pain NRS } \geq 5 \\
(N=81)\end{array}$ & $\mathrm{P}$ value \\
\hline Clinical prediction $\leq 6$ weeks & $29(38.7)$ & $52(52.6)$ & 0.001 \\
\hline ECOG $\geq 4$ & $20(24.7)$ & $38(46.9)$ & 0.003 \\
\hline Fatigue $\geq 6$ & $43(53.1)$ & $51(63.0)$ & 0.203 \\
\hline Sleep disturbance $\geq 7$ & $34(42.0)$ & $48(59.3)$ & 0.028 \\
\hline Distress $\geq 6$ & $38(46.9)$ & $46(56.8)$ & 0.208 \\
\hline Drowsiness $\geq 6$ & $34(42.0)$ & $55(67.9)$ & 0.001 \\
\hline Sadness $\geq 5$ & $33(40.7)$ & $41(50.6)$ & 0.207 \\
\hline Opioid dosage (median, range/unit: OME*, mg/d) & $19.00(0 \sim 660)$ & $60.00(0 \sim 390)$ & $<0.001$ \\
\hline
\end{tabular}

*OME: oral morphine equivalent, The categorization of variables was based on their median value.

Table 3. Multivariate Analysis of Factors Related to Substantial Pain $(\mathrm{N}=148)$.

\begin{tabular}{lcccc}
\hline & & & & \multicolumn{2}{c}{$95 \%$ confidence interval } \\
\cline { 3 - 5 } & P value & Odds ratio & Lower & Upper \\
\hline Clinical prediction of survival $\leq 6$ weeks & & 2.456 & 1.221 & 4.940 \\
Drowsiness $\geq 6$ & 0.012 & 2.061 & 1.012 & 4.197 \\
Opioid usage $\left(\mathrm{OME}^{*}\right)$ & 0.046 & 1.007 & 1.002 & 1.012 \\
\hline
\end{tabular}

*OME: oral morphine equivale, $\mathrm{mg} /$ day.

pain were $<6$ weeks predicted survival (odds ratio $(\mathrm{OR})$ : 2.456; 95\% confidence interval $(\mathrm{CI}): \quad 1.221 \sim 4.940)$ $(\mathrm{P}=0.012)$, NRS $\geq 6$ of drowsiness during last $24 \mathrm{~h}$ (OR: 2.061; 95\% CI: $1.012 \sim 4.197)(\mathrm{P}=0.046)$ and higher daily opioid dosage on admission $(\mathrm{P}=0.004$, Table 3$)$.

\section{DISCUSSION}

Three clinical factors related to substantial pain were found in our study: a clinically estimated survival of $<6$ weeks, drowsiness in the previous $24 \mathrm{~h}$ NRS $>6$, and increasing dosage of opioid analgesics.

Cancer pain has not consistently been shown to be a prognostic factor of overall survival in previous studies. The prevalence of cancer pain is reported to increase with progression of disease, from an estimated. $28 \%$ in the early stage of cancer to $64 \sim 80 \%$ in advanced cancer (12). The evidence-based recommendation for survival prediction has classified cancer pain as the factor for which a correlation has been indicated but not confirmed or for which contradictory data have emerged (13). A recent study showed positive correlation of pain with survival in metastatic prostate cancer patients. The study concluded that the pain interference score was significant predictor of overall survival and could indicate more advanced disease or disease that was refractory to therapy (14). In contrary, a recent meta-analysis did not find any difference in prevalence of pain between patients on anticancer treatment and patients with advanced or metastastic diseases (2).

Presently, patients displaying substantial pain showed significantly shorter predicted survival that those with mild pain. Although clinical estimations of survival tends to overestimate actual survival, a doctors' prediction of survival is known to be highly correlated with actual survival (15). We think that the intensity of pain might matter; if previous studies considered having more than moderate pain rather than having pain or not, then more consistent results could appear. It has been suggested that the impact of pain (pain interference) is more likely to be a better indicator for survival duration (14). This finding indicates that when moderate-to- severe pain appears in terminal cancer inpatients, their life expectancy could be reliably estimated to be $<6$ weeks, and active assessment and management of pain are required.

Drowsiness correlated positively with moderate-to-severe pain in this study. In univariate analysis, sleep disturbance 
showed a strong correlation with pain, and, as a natural outcome, drowsiness. Therefore, concerned with multicollinearity, we consulted with a biostatistician, the result was that only one variable between sleep disturbance and drowsiness should be selected in the final model of multivariate analysis. We chose drowsiness because it is a clinical outcome of sleep disturbance and because of its higher correlation with substantial pain. Sleep disturbance occurs frequently in cancer patients; its prevalence has been reported as 31 75\%, which greatly exceeds sleep disturbance in the general population (16). Sleep disturbance increases with progression of cancer; one study found that 96\% of advanced cancer patients had sleep disturbances (17). The causes of sleep disturbances are diverse and complex. Pain, adverse effects of drugs, and psychologic causes can affect sleep. One previous study demonstrated that distress from sleep disturbance was significantly correlated with pain intensity and pain distress (18). Substantial pain often interferes with sleep, therefore it can increase drowsiness in the waking hours. Conversely, insufficient sleep may decrease the threshold of pain and contribute to increased pain. As a result, a vicious circle of poor sleep and pain will occur. This bi-directional relationship is clinically relevant, and the strong association between pain and sleep has been a consistent finding of preceding studies $(19,20)$. However, most of these studies were cross-sectional, making the primary cause difficult to define. For similar reasons, the causal relation could not be sought in our study. Cancer pain is associated with difficulty falling asleep, staying asleep, and daytime sleepiness (21). Usage of opioid and benzodiazepine does not enhance quality of sleep; on the contrary, the drug use is accompanied by sleep disturbances and poor quality of life (18). Another study suggested that the use of strong opioids related more positively to poorer quality of sleep than mild opioids (22). Our results also show that the median of opioid dosage was significantly higher (60.00 $\mathrm{mg} /$ day) in drowsier individuals (NRS of drowsiness $\geq 6$ ) than less drowsy people $(22.50 \mathrm{mg} /$ day) (NRS of drowsiness $<6)(\mathrm{P}<0.001$, data not shown). However, the median of opioid dosage was not significantly different between the sleep disturbance groups $(\mathrm{P}=0.330$, data not shown). The median of the higher sleep disturbance group $(\mathrm{NRS} \geq 7)$ and lower sleep disturbance group $(\mathrm{NRS}<7)$ were $40.00 \mathrm{mg} /$ day and $30.00 \mathrm{mg} /$ day, respectively. The increment of opioid dosage was significantly related to more than moderate pain in our multivariate analysis. This is a common and readily understandable situation in palliative care. Nevertheless, to take this for granted is not always true; sufficient opioid dosage could reduce pain, thus, an inverse relationship between opioid dosage and pain intensity might be found.

Our study aimed to find factors related to substantial pain, and we speculated the factors will help to control moderate-to-severe pain. An approximately 2-fold risk of substantial pain in the drowsier group suggests some clinical implications. Drowsiness was not presently a simple reflection of opioid usage, because we adjusted opioid dosage in multivariate analysis. After adjustment, substantial pain was independently related to drowsiness. Drowsiness (including sleep disturbances) and cancer pain are inter-related and a complex relationship exists between them. We propose following attempts to support pain treatment by managing sleep or drowsiness. Considering substantial pain can disturb night sleep, it would be better to consider hypnotics besides to analgesics. Amitriptyline and mirtazapine showed better results than benzodiazepines in preceding studies $(23,24)$. Drowsiness might lead to taking a nap, which could affect normal night sleep. Therefore, clinicians can consider psychostimulants such as caffeine $(25,26)$ or methylphenidate (27) in the daytime for drowsy cancer patients.

The present study differs from previous studies regarding the classification of pain by its intensity and factors related to substantial pain. Two characteristics of patients were found to be significantly related to more than moderate pain in final model on multivariate analysis: shortened life expectancy and drowsiness. Pain is well-known to be associated with sadness, distress and fatigue (28-30). However, these associations were not significant in comparison of mild pain to substantial pain. It is possible to assume that substantial pain is deeply involved with an organic cause such as disease progression, rather than psychological causes. Substantial pain is also associated with fatigue, sadness, and distress, however its association is not stronger than that of mild pain. We recognize that to take care of fatigue, sadness in cancer patients is important and helpful to pain management. On condition that our study aims to understand factors related to substantial pain, results 
suggestive of disease progression emerged.

Our study has several limitations. First, this study was a cross-sectional study and used secondary data. It cannot reveal causal relationships between factors and substantial pain. We could not collect prospectively important information such as depression, metastasis and types of pain. Second, the study subjects were all terminal cancer inpatients of palliative wards in teaching hospitals. Therefore generalization to all terminal cancer patients is limited. However, we tried to compensate regional or institutional bias by multicenter involvement. Third, survival estimates of clinicians were not to be compared to actual survival. Although clinical estimation of survival tends to overestimate actual survival, it is well correlated with actual survival and has unique validity. Clinical estimation of survival is an essential tool for palliative care, and we think it also helps to approach cancer pain. Fourth, the assessment tool for psychological symptoms was a relatively simple one. We used the Korean version of the MD Anderson Symptom Inventory to assess sadness, drowsiness and distress. This is a validated tool (2) to assess various symptoms of cancer patients in Korea (11). Administration of a lengthy questionnaire or various questionnaires was neither practical nor desirable in emaciated terminal patients. A simple validated tool is available for terminal patients, and its usage is should be encouraged to promote palliative care research.

A recent meta-analysis of 52 articles showed more than one-third of patients with pain graded their pain as moderate or severe (NRS>4) (2). Most patients will accept mild pain, whereas moderate and severe pain requires attention. They perceived that moderate to severe pain had a much greater impact on daily life than mild pain (7). Cancer pain still is a major problem despite the various global education projects and clear recommendations.

Our study confirms that the prevalence of moderate-to-severe pain is quite high and that effective pain management is promptly required. To maintain human dignity is very important in end-of-life care, management of various symptoms including cancer pain is essential to reach this goal (1). We suggested that intervention to sleep would help to relief pain because drowsiness was significantly related to more than moderate pain. We found clinical prediction of survival to be associated with substantial pain.
A patient's life expectancy definitely cannot be altered, however with the guide of a reliable estimate of predicted survival, close attention and preparedness for increasing pain will be possible. Well-designed studies are needed to prove our suggestion in the future.

\section{요 약}

목적: 암환자에게 통증은 가장 흔하고 영향이 큰 증 상이다. 그러나 말기암환자에서 통증 강도에 대한 연 구는 부족하였다. 본 연구는 중등도 이상의 통증과 연 관된 요인을 밝히고자 한다.

방법: 우리나라 완화의료 기관 6곳의 입원 병동을 대 상으로 말기 암 환자 162 명 자료를 사용하였다. 통증 은 담당의가 10 점 만점 숫자통증등급으로 측정하였다. 중등도 이상의 통증은 보건복지부 지침의 정의에 따랐 다. 증상 평가에는 $\mathrm{MD}$ Anderson 증상 평가조사지 한국 어본을 활용하였다. 생존기간 예측은 입원 당시 담당 전문의가 하였다.

결과: 예측 생존 기간이 6주 미만인 경우와 지난 24 시간 졸린 정도가 6점 이상인 경우가 중등도 이상의 통증과 유의하게 연관되었다(각각 $\mathrm{P}=0.012, \mathrm{P}=0.046$ ). 마약성 진통제 투여량도 중등도 이상의 통증에 비례하 였다 $(\mathrm{P}=0.004)$.

결론: 중등도 이상의 통증과 유의하게 연관된 요인 은 예측 생존 기간이 6주 미만인 것과 상당한 졸림이 었다. 이러한 요인을 나타내는 말기 암 환자에서 주의 깊은 통증의 감시와 적극적인 대비가 필요하다.

중심단어: 암성통증, 예측 생존기간, 졸림

\section{REFERENCES}

1. Modonesi C, Scarpi E, Maltoni M, Derni S, Fabbri L, Martini $\mathrm{F}$, et al. Impact of palliative care unit admission on symptom control evaluated by the edmonton symptom assessment system. J Pain Symptom Manage 2005;30:367-73.

2. van den Beuken-van Everdingen $\mathrm{MH}$, de Rijke JM, Kessels AG, Schouten HC, van Kleef M, Patijn J. Prevalence of pain in patients with cancer: a systematic review of the past 40 years. Ann Oncol 2007;18:1437-49.

3. Vallerand AH, Templin T, Hasenau SM, Riley-Doucet C. Factors that affect functional status in patients with cancer-related pain. Pain 2007;132:82-90. 
4. WHO: WHO's pain ladder [Internet]. Geneva: World Health Organization; c2011. Available from: http://www.who.int/cancer/ palliative/painladder/en/.

5. Yun YH, Heo DS, Lee IG, Jeong HS, Kim HJ, Kim SY, et al. Multicenter study of pain and its management in patients with advanced cancer in Korea. $J$ Pain Symptom Manage 2003;25:430-7.

6. Jensen MP, Karoly P, Braver S. The measurement of clinical pain intensity: a comparison of six methods. Pain 1986;27:117-26.

7. Serlin RC, Mendoza TR, Nakamura Y, Edwards KR, Cleeland CS. When is cancer pain mild, moderate or severe? Grading pain severity by its interference with function. Pain 1995;61:277-84.

8. National Cancer Information Center (NCIC), Chapter 2. Pharmacotherapy of cancer pain. In: NCIC. Cancer Pain Management Guideline. Version 3.1. Ministry for health, welfare and family affairs;2008. p. 15.

9. Yun YH, Mendoza TR, Heo DS, Yoo T, Heo BY, Park HA, et al. Development of a cancer pain assessment tool in Korea: a validation study of a Korean version of the brief pain inventory. Oncology 2004;66:439-44.

10. Suh SY, Choi YS, Shim JY, Kim YS, Yeom CH, Kim D, et al. Construction of a new, objective prognostic score for terminally ill cancer patients: a multicenter study. Support Care Cancer 2009.

11. Yun YH, Mendoza TR, Kang IO, You CH, Roh JW, Lee CG, et al. Validation study of the Korean version of the M. D. Anderson Symptom Inventory. J Pain Symptom Manage 2006;31:345-52.

12. Doyle D, Hanks GW, MacDonald N. Oxford textbook of palliative medicine. 2th ed. New York:Oxford University Press; 1998.

13. Maltoni M, Caraceni A, Brunelli C, Broeckaert B, Christakis N, Eychmueller S, et al. Prognostic factors in advanced cancer patients: evidence-based clinical recommendations--a study by the Steering Committee of the European Association for Palliative Care. J Clin Oncol 2005;23:6240-8.

14. Halabi S, Vogelzang NJ, Kornblith AB, Ou SS, Kantoff PW, Dawson NA, et al. Pain predicts overall survival in men with metastatic castration-refractory prostate cancer. J Clin Oncol 2008;26:2544-9.

15. Vigano A, Dorgan M, Bruera E, Suarez-Almazor ME. The relative accuracy of the clinical estimation of the duration of life for patients with end of life cancer. Cancer 1999;86:170-6.

16. Clark J, Cunningham M, McMillan S, Vena C, Parker K. Sleep-wake disturbances in people with cancer part II: evaluating the evidence for clinical decision making. Oncol Nurs
Forum 2004;31:747-71.

17. Mystakidou K, Parpa E, Tsilika E, Gennatas C, Galanos A, Vlahos L. How is sleep quality affected by the psychological and symptom distress of advanced cancer patients? Palliat Med 2009; 23:46-53.

18. McMillan SC, Tofthagen C, Morgan MA. Relationships among pain, sleep disturbances, and depressive symptoms in outpatients from a comprehensive cancer center. Oncol Nurs Forum 2008;35:603-11.

19. Rumble ME, Keefe FJ, Edinger JD, Porter LS, Garst JL. A pilot study investigating the utility of the cognitive-behavioral model of insomnia in early-stage lung cancer patients. J Pain Symptom Manage 2005;30:160-9.

20. Sayar K, Arikan M, Yontem T. Sleep quality in chronic pain patients. Can J Psychiatry 2002;47:844-8.

21. Palesh OG, Collie K, Batiuchok D, Tilston J, Koopman C, Perlis ML, et al. A longitudinal study of depression, pain, and stress as predictors of sleep disturbance among women with metastatic breast cancer. Biol Psychol 2007;75:37-44.

22. Mystakidou K, Parpa E, Tsilika E, Pathiaki M, Gennatas K, Smyrniotis V, et al. The relationship of subjective sleep quality, pain, and quality of life in advanced cancer patients. Sleep 2007;30:737-42.

23. Kautio AL, Haanpaa M, Saarto T, Kalso E. Amitriptyline in the treatment of chemotherapy-induced neuropathic symptoms. J Pain Symptom Manage 2008;35:31-9.

24. Kim SW, Shin IS, Kim JM, Kim YC, Kim KS, Kim KM, et al. Effectiveness of mirtazapine for nausea and insomnia in cancer patients with depression. Psychiatry Clin Neurosci 2008; 62:75-83.

25. Manfredi PL, Gonzales GR. Symptomatic uses of caffeine in patients with cancer. J Palliat Care 2003;19:63-5.

26. Mercadante S, Serretta R, Casuccio A. Effects of caffeine as an adjuvant to morphine in advanced cancer patients. A randomized, double-blind, placebo-controlled, crossover study. J Pain Symptom Manage 2001;21:369-72.

27. Bruera E, Watanabe S. Psychostimulants as adjuvant analgesics. J Pain Symptom Manage 1994;9:412-5.

28. Spiegel D, Sands S, Koopman C. Pain and depression in patients with cancer. Cancer 1994;74:2570-8.

29. Mystakidou K, Tsilika E, Parpa E, Pathiaki M, Patiraki E, Galanos $A$, et al. Exploring the relationships between depression, hopelessness, cognitive status, pain, and spirituality in patients with advanced cancer. Arch Psychiatr Nurs 2007;21:150-61.

30. Echteld MA, van Zuylen L, Bannink M, Witkamp E, Van der Rijt CC. Changes in and correlates of individual quality of life in advanced cancer patients admitted to an academic unit for palliative care. Palliat Med 2007;21:199-205. 